\title{
Performance degradation and analysis of 10-cell anode- supported SOFC stack with external manifold structure
}

\author{
Dong Yan ${ }^{\mathrm{a}}$, Lingjiang Liang, ${ }^{\mathrm{a}}$, Jiajun Yang ${ }^{\mathrm{a}}$, Tao Zhang ${ }^{*}$, Jian Pu ${ }^{\mathrm{a}}$, Bo Chi ${ }^{\mathrm{a}}$, Jian $\mathrm{Li}^{\mathrm{a}}$ \\ ${ }^{a}$ School of Materials Science and Engineering, State Key Laboratory of Material Processing and Die \& \\ Mould Technology, Huazhong University of Science \& Technology, 430074 Wuhan, Hubei, China \\ ${ }^{\mathrm{b}}$ School of Naval Architecture \& Ocean Engineering, Huazhong University of Science \& Technology, \\ 430074 Wuhan, Hubei, China
}

\begin{abstract}
:
This study describes the development of solid oxide fuel cell (SOFC) stack with external manifold structure. The stack used anode supported cells with size of $11 \mathrm{~cm} \times 11 \mathrm{~cm}$ which are fabricated by tape casting, screen-printing and co-sintering. Computer simulation was employed to evaluate the gas distribution in the external manifold stack. The 10 -cell stack was operated at $750^{\circ} \mathrm{C}$ with hydrogen as fuel and air as oxidant and generated output power of $360 \mathrm{~W}$, corresponding to power density of $440 \mathrm{~mW} / \mathrm{cm}^{2}$. The degradation performance was investigated for over $750 \mathrm{~h}$ under the current density of $370 \mathrm{~mA} / \mathrm{cm}^{2}$. Posttest analysis of the SOFC stack was operated to investigate the factors related to the performance degradation such as microstructure of electrodes, sealing, contact resistance and oxidation of metal interconnect. The study presented here showed the stack with external manifold can be considered as a strong candidate for SOFC stack design.
\end{abstract}

Keywords: Solid oxide fuel cell; stack; Performance durability; Microstructure analysis; oxidation

\section{Introduction}

Solid oxide fuel cell is gaining more attention in recent years. It is considered as a promising power generation technology due to its high efficiency, low emission and high fuel flexibility[1-3]. However, the durability and cost are still the major challenges towards commercialization in long term operation[4-6]. Depending on considerable progress in SOFC materials system, the operating temperature of the stack has been reduced from $1000^{\circ} \mathrm{C}$ to the range of $600 \sim 800^{\circ} \mathrm{C}$, thus, cheaper metals like stainless steel can be used as interconnect which makes SOFCs technology more attractive[7-9].

\footnotetext{
*zhangt7666@hust.edu.cn
} 
Planar type anode-supported cell is a promising one which has been confirmed to have high power density and reliability[10]. In our previous work, the fabrication process and performance of single cell have been investigated. The cell with active area of $81 \mathrm{~cm}^{2}$ can obtain an $\mathrm{OCV}$ (open circuit voltage) of $1.2 \mathrm{~V}$ and power density of $770 \mathrm{~mW} / \mathrm{cm}^{2}$ at the current density of $950 \mathrm{~mA} / \mathrm{cm}^{2}$ and its performance degradation is lower than $1.56 \% / 1000 \mathrm{~h}[11]$. However, when cells are assembled into a stack to achieve higher power outputs, the stack performance will be unavoidable affected by several inherent issues, especially like surface contact resistance, gas distribution, sealing, oxidation of metallic interconnect, which have been confirmed by researches[12-14].

Although considerable progresses have already been achieved in improving the initial stack performance by enhancing cell and interface contact[15], the stack stability remains a critical concern for SOFC development. The degradation mechanism of stack has been investigated in the recent decades. The general degradation features include deactivation of catalysts, oxidation of metallic component, element diffusion and chemical reaction, microstructure changes from electrode, sealing failure, etc. which is difficult to examine and identify the degradation origin[16-19]. As described in the literature[20], two parameters, area-specific resistance (ASR) and degradation rate (DR) are proposed to evaluate the degradation behavior. The increase of ASR was widely believed to be the result of degradation.

Different types of stack have been invented like internal-manifold type[21,22], external-manifold type[23, 24], envelope type[25] disc type[26], etc. Within these types, the external manifolds are simple in structure and cost less to build. We have already built and tested a 3-cell stack and described the gas flow and temperature distribution in the stack with the help of computer simulation in our previous work [24].

Based on previous researches [11, 24, 27, 28], the gas distribution in the stack is evaluated with computational fluid dynamic method. A 10-cell stack was built and evaluated during a long-time operation. The effect of cell microstructure, cathode contact materials, sealing and oxidation of metallic interconnect on performance degradation of stack is discussed in detail as well as intensive post-test analysis.

\section{Stack configuration and simulation}


Fig.1 shows the schematic diagram of the external-manifold SOFC stack with cross-flow configuration. The serially connected cells in the stack are fed with gas in parallel. If fuel starvation developed in some of the cells, the whole stack performance will be affected. High current density may reverse the electric potential of the starving cells, oxide the anode and lead to structural failure. Gas distribution was investigated by computer simulation before the stack was assembled. A 3D module of the manifold in full scale was built as shown in Fig.2 (a). The gas flow rate of each cell was set to be $0.8 \mathrm{SLM}$ and the cells were numbered from top to bottom. For an open manifold without outlet back pressure, the gas distribution is uneven and the middle cell has the lowest mass flow rate as shown in Fig.2 (b). This result represents the situation of absence of stack core, without the current collectors in the stack providing resistance for the gas flow. By increasing the back pressure to $600 \mathrm{~Pa}$ and $1200 \mathrm{~Pa}$, the mass flow rates between each cell improved their uniformity as shown in Fig.2 (c) and (d). The flow rate fluctuation reduced from $\pm 18 \%$ for 0 Pa to $\pm 0.09 \%$ and $\pm 0.07 \%$ for 600 $\mathrm{Pa}$ and $1200 \mathrm{~Pa}$ respectively. Judging from the calculation results, the manifold flow chamber is capable to provide a uniform flow distribution for the 10-cell stack core.

\section{Experimental}

\subsection{Stack construction}

The Ni foam was used as current collector and gas distributor for the anode. In order to eliminate the mismatch of coefficient of thermal expansion between interconnect and manifold, stainless steel SUS 430 was used to fabricate all the metallic components. Detail of the integrated interconnect has been described elsewhere[24]. As previously reported[27], the anode supported cells were fabricated by tape casting, screen printing, and single step co-fire process. The Cells have dimensions and active area of $11 \times 11 \mathrm{~cm}^{2}$ and $9 \times 9 \mathrm{~cm}^{2}$ respectively. To enhance the ability of current collection, a layer of $\mathrm{LaCo}_{0.6} \mathrm{Ni}_{0.4} \mathrm{O}_{3-\delta}$ ( $\mathrm{LCN}$ ) was applied between the cathode and current collector. The electronic conductivity of $\mathrm{LCN}$ is above $1000 \mathrm{~S} / \mathrm{cm}$ at $800^{\circ} \mathrm{C}$, higher than conventional cathode contact materials LSM and LNF[29]. The powder was pre-calcined at $1100^{\circ} \mathrm{C}$ for 3 hours to prevent grain coarsening during the operation at $750{ }^{\circ} \mathrm{C}$. In this study, the cell was sealed by flexible alumina-based strip-shape tapes developed from our previous work $[13,30]$. The thickness of sealing tape was optimized to meet a precise match with cell and corrugation plate that can 
achieve good contact and sealing at the same time.

\subsection{Stack operation and post analysis}

The 10-cell stack was heated from room temperature to the operating temperature of $750^{\circ} \mathrm{C}$ in the furnace. The inlet gases were heated while passing through coiled steel tubes inside the furnace. The cathode was fed with dry air and the anode was fed with nitrogen and 4 vol. \% of hydrogen mixture gas so that the $\mathrm{NiO}$ in the anode can be gradually reduced. Upon reaching $750^{\circ} \mathrm{C}$, the gas of anode side was changed to pure hydrogen. The voltage and power density of stack as a function of current density were measured under current passage ranging from 0 to $60 \mathrm{~A}$. The stack with more than $700 \mathrm{~h}$ operating time was tested under current density of $370 \mathrm{~mA} / \mathrm{cm}^{2}$ for evaluating the performance stability at long time operation. During the operation, flammable gas detectors were deployed in the testing room to detect hydrogen leaking, exhaust fans were also used to ensure the ventilation. When the test ended, the stack was cooled down to the room temperature under hydrogen atmosphere of anode side.

The stack was then disassembled and examined. The cell microstructure, morphology of the LCN powder and oxide scale of interconnect were characterized by scanning electron microscopy (SEM, FEI quanta 200, Phillips) and energy dissipation spectroscope (EDS, AMETEK). The phase structure of anode and LCN were identified by X-ray diffraction (XRD, X'Pert PRO diffractometer).

\section{Results and discussion}

\subsection{Electrical performance and degradation of stack}

Fig.3 shows the stack voltage and power density as functions of current density in 10-cell stack. The open circuit voltage (OCV) of $11.79 \mathrm{~V}$ and power density of 440 $\mathrm{mW} / \mathrm{cm}^{2}$ (power of $360 \mathrm{~W}$ ) were achieved at the current density of $740 \mathrm{~mA} / \mathrm{cm}^{2}$ (current of $60 \mathrm{~A}$ ). It can be inferred that the sealant did not met severe failure like cracks or delamination which could lead to massive gas leaking and internal combustion, according to the high OCV, and the adjacent components in the stack contacted well with each other and resulted a low electrical resistance in testing. The area specific resistance (ASR) of stack was $0.44 \Omega \cdot \mathrm{cm}^{2}$ calculated from the linear portion of voltage-current curve, which is twice the value of the single cell ASR of only $0.202 \Omega \cdot \mathrm{cm}^{2}$ [11]. This difference between cell and stack depends on stack structure, components connect and materials combinations, and some problems like gas distribution, interface contact and sealing can often occur on stack other than cell, 
leading to unwanted performance degradation. Dey et al.[12] suggest that the loss of actual contact area (2.5\% on the anode and $6.7 \%$ on cathode) for cell electrode plays critical roles towards the performance of the scaled up cell. Obviously, the initial performance difference can be mainly ascribed to the contact resistance between cell and the adjacent components when cell structure is almost the same.

The long term stability was characterized by the voltage degradation when the stack was discharging at a constant current. The degradation was mainly caused by electrochemical and ohmic resistance increasing. A working voltage model has been developed to discuss the degradation mechanism of stack according to the equation[20]:

$V(i, t)=\left(E_{N}-\eta_{L}\right)-\left(i R_{i}+\eta_{\text {aa }}+\eta_{\text {ac }}+\eta_{c a}+\eta_{c c}\right)$

Where $\mathrm{V}$ is the stack voltage, $\mathrm{i}$ is the current density, $\mathrm{t}$ is the time, $\mathrm{E}_{\mathrm{N}}$ is the Nernst potential, $R_{i}$ is the total resistance of all cell components, $y_{L}$ is the loss caused by leakage, $\eta_{\mathrm{aa}}$ and $\eta_{\mathrm{ac}}$ are the activation over potentials of anode and cathode, $\eta_{\mathrm{ca}}$ and $\eta_{\mathrm{cc}}$ are the concentration over potentials, respectively. Additionally, the definitions of ASR and average DR in terms of the Eq. (1) are:

$\operatorname{ASR}\left(i_{s}, t\right)=\frac{E(t)-V\left(i_{s}, t\right)}{i_{s}}$

And,

$\overline{D R}(\mathrm{t})=100 \frac{\mathrm{V}\left(\mathrm{i}_{\mathrm{s}}, \mathrm{t}_{0}\right)-\mathrm{V}\left(\mathrm{i}_{\mathrm{s}}, \mathrm{t}\right)}{\mathrm{V}\left(\mathrm{i}_{\mathrm{s}}, \mathrm{t}_{0}\right) \times\left(\mathrm{t}-\mathrm{t}_{0}\right)}$

Where $\mathrm{E}$ can be either the ideal Nernst potential or OCV, $\mathrm{i}_{\mathrm{s}}$ is the constant operating system current density, and $\mathrm{t}_{0}$ can be described as the initial starting time. Fig. 4 shows the voltage degradation of 10-cell stack with current density of $370 \mathrm{~mA} / \mathrm{cm}^{2}$, taken operation time at $700 \mathrm{~h}$. The stack voltage increased from $8.02 \mathrm{~V}$ to $8.55 \mathrm{~V}$ at the initial stage of the polarization, and then decreased slowly to $7.46 \mathrm{~V}$. According to the Eqs. (2) and (3), the ASR and average DR were calculated and shown as a function of time in the Fig.5. The average DR of the stack for $700 \mathrm{~h}$ was $17.6 \% / 1000 \mathrm{~h}$, which displays a clearly linear degradation. The ASR increased from $0.88 \Omega \cdot \mathrm{cm}^{2}$ to 1.17 $\Omega \cdot \mathrm{cm}^{2}$ per cell. Generally, the performance degradation of stack originated from ASR increase may be ascribed to several reasons including microstructure coarsening of cell, oxidation of metallic interconnect, mechanical delamination between electrode/interconnect interface, and leakage driven degradation.

\subsection{Degradation analysis}

\subsubsection{Cell structure}


After the test, the stack was disassembled and cells were examined. None of the cells was broken and delaminated. The CTE mismatch among sealant, interconnect and the cell or the manifold did not develop thermal stress high enough to break the cell.

The cross sectional microstructure of cell is shown in Fig.6. The thin dense electrolyte is almost free of pore or cracks, and well bonded to the porous cathode and functional anode. Further, the porous electrode provides the gas diffusion path to the triple phase boundary near the electrolyte.

Fig.7 shows the XRD patterns of anode sides before and after reduction with electrolyte carefully removed by polishing to expose the anode functional layer.. Peaks are denoted with JCPDF file 00-001-1258 for Ni, 00-001-1239 for NiO and 00-037-1307 for YSZ. Result shows that NiO had been fully reduced to metallic Ni and no other phase formed, the materials of cell remained stable during the test.

\subsubsection{Contact}

Fig.8 gives the $\mathrm{X}$-ray diffraction patterns of cathode contact material $\mathrm{LaCo}_{0.6} \mathrm{Ni}_{0.4} \mathrm{O}_{3-\delta}$ layer before and after test and compare those with the JCPDF file 00-054-0834. The peaks match well and no difference can be observed. It can be confirmed that the LCN has a chemical compatibility both with cathode and interconnector in the cathode atmosphere under operational temperature and remains stable during the operation, which is in agreement with previously reported results[29]. The morphologies and particle sizes of LCN powder before (a) and after (b) test are shown in Fig.9. Both LCN powders had similar mean grain size of about $1.5 \mu \mathrm{m}$, while the particle after test had narrower size distribution and morphology showed sintering neck between neighboring particles. It is noted that the neck-contacted LCN particles could remain the geometric dimension and microstructure during the operation basically, although the grain coarsening and formation of sintering neck might bring the shrinkage of the LCN layer increasing the contact resistance. Low temperature sintering could happen in contact materials according to the report of McCarthy et al.[31]. The pre-calcine treatment at higher temperature could effectively reduce the particle surface energy and thus stable the microstructure and prevent particle growth.

In order to evaluate the degradation of LCN contact layer, the ASR of LCN was measured under a simulation environment with four-probe method and the results 
were shown in Fig.10 companied by the schematic diagram, a layer of LCN slurry was sandwiched between two SUS430 steel plate and was heat to $750{ }^{\circ} \mathrm{C}$. During the simulation test, the ASR increased from $70 \mathrm{~m} \Omega \cdot \mathrm{cm}^{2}$ to $130 \mathrm{~m} \Omega \cdot \mathrm{cm}^{2}$ in first $50 \mathrm{~h}$ and slowly went up to $160 \mathrm{~m} \Omega \cdot \mathrm{cm}^{2}$ in $200 \mathrm{~h}$. Based on the fitting of the curve, the total ASR increment was $100 \mathrm{~m} \Omega \cdot \mathrm{cm}^{2}$ at $700 \mathrm{~h}$. Subtracting the increment of $10 \mathrm{~m} \Omega \cdot \mathrm{cm}^{2}$ caused by steel oxidation calculated according to the previous research[32], the ASR increment caused by LCN degradation was $90 \mathrm{~m} \Omega \cdot \mathrm{cm}^{2}$, contributing to $31 \%$ of total degradation $\left(290 \mathrm{~m} \Omega \cdot \mathrm{cm}^{2}\right)$.

\subsubsection{Sealant}

Fig.11(a) shows the photograph of cathode side. Part of the black contact layer was carried away by the current collector and cathode surface was exposed. At the edge of the contact area, some LCN powder's color turned into dark brown. Samples were taken from these region and characterized by XRD, Result shown in Fig.11 (b) suggested that the LCN powder was decomposed into $\mathrm{La}_{2} \mathrm{O}_{3}, \mathrm{LaCrO}_{3}$, and $\mathrm{LaNiO}_{3}$, which have higher resistance than LCN. This change will increase the ASR, reduce the active area and increase the current density in the active area. Consider the position where decomposition happened, we suspect that there was a sealing failure in these area. When $\mathrm{H}_{2}$ invaded into the cathode side from the edge, burning elevated the local temperature and also changed the oxygen partial pressure to a condition that LCN couldn't retain stable and decomposed. On the anode side, no burning mark of air leakage was found and the sealant remained relatively intact shown in Fig.12. Meanwhile, the Ni foam was firmly adhered with cell and interconnect indicating a good contact. Although excellent performance was achieved at simulated out-of-stack leak test and single cell test[33], the sealant might be broken down at severer SOFC stack operation condition including high temperature gradient, rigorous reducing and oxidizing environment and uneven stress distribution and past experimental results revealed that the gas leakage through interface of sealant and cell/interconnect takes the dominant part.

\subsubsection{Interconnect oxidation}

Fig.13 shows the cross-sectional microstructures of interconnect (anode side) and corrugation (cathode side), and EDS compositional profile of line scan across the oxide scale. The scale was less than $5 \mu \mathrm{m}$ thick and well bonded on the metallic substrate. The EDS result shown in Fig.13 reveals a double layer structure, with higher $\mathrm{Mn}$ content in the outer layer, higher $\mathrm{Cr}$ content in the inner layer and absence 
of Fe. According to the reported literature[8, 34], the scale is composed of $\mathrm{MnCr}_{2} \mathrm{O}_{4}$ on top of $\mathrm{Cr}_{2} \mathrm{O}_{3}$. The absence of $\mathrm{Fe}$ in the scale means the dense oxidant layer acted as a protective layer and prevented the oxidation of Fe.

Theoretically, the ASR can be calculated by the expression as a combination of the electrical resistivity $(\rho)$ and the thickness $(t)$ of the oxide scale:

$$
\mathrm{ASR}=\rho_{\mathrm{Cr}_{2} \mathrm{O}_{3}} \Delta t_{\mathrm{Cr}_{2} \mathrm{O}_{3}}+\rho_{\mathrm{MnCr}_{2} \mathrm{O}_{4}} \Delta t_{\mathrm{MnCr}_{2} \mathrm{O}_{4}}+\rho_{\mathrm{Fe}_{2} \mathrm{O}_{3}} \Delta t_{\mathrm{Fe}_{2} \mathrm{O}_{3}}
$$

Where $\rho_{\mathrm{Cr}_{2} \mathrm{O}_{3}}, \rho_{\mathrm{Fe}_{2} \mathrm{O}_{3}}$ and $\rho_{\mathrm{MnCr}_{2} \mathrm{O}_{4}}$ are the constant with values of $78 \Omega \cdot \mathrm{cm}[35]$, $9.2 \Omega \cdot \mathrm{cm}$ and $0.5 \Omega \cdot \mathrm{cm}[36]$. Thus, the total estimated ASR value of the oxidant was 82 $\mathrm{m} \Omega \cdot \mathrm{cm}^{2}$ and the equivalent cell voltage decrement caused by oxidation was $0.03 \mathrm{~V}$, making up $29 \%$ of the stack degradation. The oxidation of metallic interconnect is inevitable, which is deteriorate to the performance of stack after long oxidation in SOFC operation environment.

Thus, it can be tentatively concluded that the oxidation of interconnect, the degradation of cathode contact material LCN, seal failure and other issues made great contribution to the performance degradation shown in Fig.14.

\section{Conclusions}

We have developed an external manifold SOFC stack using a simple interconnect with corrugation plate. Flow simulation by computer finds out that the gas flow in the manifold can maintain a relative uniformity and the difference between each cell was less than $\pm 0.1 \%$ for the 10 cells with the proper flow resistance. The stack composed of 10 anode-supported SOFCs and provided an OCV of $11.79 \mathrm{~V}$ and output of 440 $\mathrm{mW} / \mathrm{cm}^{2}$ (power of $360 \mathrm{~W}$ ). The long term performance of the stack for $700 \mathrm{~h}$ was conducted and the degradation behavior was discussed. The average degradation rate was $17.6 \% / 1000 \mathrm{~h}$ at the current density of $370 \mathrm{~mA} / \mathrm{cm}^{2}$. In the post test examination, we have investigated several issues related to degradation including contact decaying, oxidation of interconnects and sealing. Although the contact material was pre-calcined to prevent low temperature sintering, there was still a minor microstructure change, and the ASR of the LCN contact material increased and contributes almost 1/3 of the degradation. Stainless steel interconnect oxidation provided another $1 / 3$ of the total degradation as the uncoated steel operated under complex atmospheres with a relative high current density. Sealant retained intact during the test, but there is still a leaking at some part of the stack, this yield the decomposition of LCN contact material and also provided performance degradation. These are believed to contribute most of the 
stack degradation and should be improved in the future work.

\section{Acknowledgment}

This work was supported by the National Science Foundation of China [grant number 51572099]; the "863" high-tech project [grant number 2011AA050702]. The XRD characterizations and SEM analysis were assisted by the Analytical and Testing Center of Huazhong University of Science and Technology.

\section{REFERENCES}

[1] Jiao Y, Zhang L, An W, Zhou W, Sha Y, Shao Z, Bai J, Li SD. Controlled deposition and utilization of carbon on Ni-YSZ anodes of SOFCs operating on dry methane, Energy. 2016;113:432-43

[2] Duan L, Huang K, Zhang X, Yang Y. Comparison study on different SOFC hybrid systems with zero-CO2 emission. Energy. 2013;58:66-77.

[3] Zhang L, Li X, Jiang JH, Li SH, Yang J, Li J. Dynamic modeling and analysis of a $5-\mathrm{kW}$ solid oxide fuel cell system from the perspectives of cooperative control of thermal safety and high efficiency. International Journal of Hydrogen Energy. 2015;40:456-476.

[4] Roshandel R, Parhizkar T. Degradation based optimization framework for long term applications of energy systems, case study: Solid oxide fuel cell stacks. Energy. 2016:107:172-181

[5] Andújar JM, Segura F. Fuel cells: History and updating. A walk along two centuries. Renewable and Sustainable Energy Reviews. 2009;13:2309-22.

[6] Minh N. Solid oxide fuel cell technology - features and applications. Solid State Ionics. 2004;174:271-7.

[7] Yang Z. Recent advances in metallic interconnects for solid oxide fuel cells. International Materials Reviews. 2008;53:39-54.

[8] Hua B, Pu J, Lu F, Zhang J, Chi B, Jian L. Development of a Fe-Cr alloy for interconnect application in intermediate temperature solid oxide fuel cells. Journal of Power Sources. 2010;195:2782-8.

[9] Bae J, Lim S, Jee H, Kim JH, Yoo Y-S, Lee T. Small stack performance of intermediate temperature-operating solid oxide fuel cells using stainless steel interconnects and anode-supported single cell. Journal of Power Sources. 2007;172:100-7.

[10] Yokoo M, Tabata Y, Yoshida Y, Orui H, Hayashi K, Nozaki Y, et al. Development 
of $1 \mathrm{~kW}$ class solid oxide fuel cell stack using anode-supported planar cells. Journal of Power Sources. 2008;184:84-9.

[11]Wang J, Yan D, Pu J, Chi B, Jian L. Fabrication and performance evaluation of planar solid oxide fuel cell with large active reaction area. International Journal of Hydrogen Energy. 2011;36:7234-9.

[12]Dey T, Ghosh PC, Singdeo D, Bose M, Basu RN. Diagnosis of scale up issues associated with planar solid oxide fuel cells. International Journal of Hydrogen Energy. 2011;36:9967-76.

[13]Dai Z, Pu J, Yan D, Chi B, Jian L. Thermal cycle stability of Al2O3-based compressive seals for planar intermediate temperature solid oxide fuel cells. International Journal of Hydrogen Energy. 2011;36:3131-7.

[14]Jin L, Guan W, Niu J, Ma X, Wang WG. Effect of contact area and depth between cell cathode and interconnect on stack performance for planar solid oxide fuel cells. Journal of Power Sources. 2013;240:796-805.

[15]Liu YH, Chen J, Wang FZ, Chi B, Pu J, Jian L. Performance stability of impregnated $\mathrm{La} 0.6 \mathrm{Sr} 0.4 \mathrm{Co} 0.2 \mathrm{Fe} 0.8 \mathrm{O} 3$-delta-Y2O3 stabilized $\mathrm{ZrO} 2$ cathodes of intermediate temperature solid oxide fuel cells. International Journal of Hydrogen Energy. 2014;39:3404-3411.

[16] Virkar AV. A model for solid oxide fuel cell (SOFC) stack degradation. Journal of Power Sources. 2007;172:713-24.

[17]Fang Q, Blum L, Batfalsky P, Menzler NH, Packbier U, Stolten D. Durability test and degradation behavior of a $2.5 \mathrm{~kW}$ SOFC stack with internal reforming of LNG. International Journal of Hydrogen Energy. 2013;38:16344-53.

[18]Mehrana MT, Lima TH, Leea SB, Leea JW, Parka SJ, Song RH. Long-term performance degradation study of solid oxide carbon fuel cells integrated with a steam gasifier. Energy. 2016;113:1051-1061.

[19]Laurencin J, Delette G, Lefebvre-Joud F, Dupeux M. A numerical tool to estimate SOFC mechanical degradation: Case of the planar cell configuration. Journal of the European Ceramic Society. 2008;28:1857-69.

[20]Gemmen RS, Williams MC, Gerdes K. Degradation measurement and analysis for cells and stacks. Journal of Power Sources. 2008;184:251-9.

[21] Yokoo M, Tabata Y, Yoshida Y, Hayashi K, Nozaki Y, Nozawa K, et al. Highly efficient and durable anode-supported SOFC stack with internal manifold structure. Journal of Power Sources. 2008;178:59-63. 
[22] Bunina GA, Wuilleminb Z, Françoisa G, Nakajob A, Tsikonisb L, Bonvin D. Experimental real-time optimization of a solid oxide fuel cell stack via constraint adaptation. 2012;39:54-62.

[23]Chung BW, Chervin CN, Haslam JJ, Pham A-Q, Glass RS. Development and Characterization of a High Performance Thin-Film Planar SOFC Stack. Journal of The Electrochemical Society. 2005;152:A265.

[24] Yan D, Bin Z, Fang D, Luo J, Wang X, Pu J, et al. Feasibility study of an external manifold for planar intermediate-temperature solid oxide fuel cells stack. International Journal of Hydrogen Energy. 2013;38:660-6.

[25] Yoshida H, Yakabe H, Ogasawara K, Sakurai T. Development of envelope-type solid oxide fuel cell stacks. Journal of Power Sources. 2006;157:775-81.

[26]Nishiwaki F, Inagaki T, Kano J, Akikusa J, Murakami N, Hosoi K. Development of disc-type intermediate-temperature solid oxide fuel cell. Journal of Power Sources. 2006;157:809-15.

[27]Luo J, Yan D, Fang D, Liang F, Pu J, Chi B, et al. Electrochemical performance and thermal cyclicability of industrial-sized anode supported planar solid oxide fuel cells. Journal of Power Sources. 2013;224:37-41.

[28] Wei S.-S, Wang T.-H, Wu J.-S. Numerical modeling of interconnect flow channel design and thermal stress analysis of a planar anode-supported solid oxide fuel cell stack. Energy, 2014;69:553-61.

[29]Wang F, Yan D, Zhang W, Chi B, Pu J, Jian L. LaCo0.6Ni0.4O3- $\delta$ as cathode contact material for intermediate temperature solid oxide fuel cells. International Journal of Hydrogen Energy. 2013;38:646-51.

[30]Wang X, Yan D, Fang D, Luo J, Pu J, Chi B, et al. Optimization of Al2O3-glass composite seals for planar intermediate-temperature solid oxide fuel cells. Journal of Power Sources. 2013;226:127-33.

[31]B.P. McCarthy, L.R. Pedersona, Y.S. Chou, X.-D. Zhou, W.A. Surdoval, L.C. Wilson. Low-temperature sintering of lanthanum strontium manganite-based contact pastes for SOFCs. Journal of Power Sources. 2008;180:294-330.

[32]Jian P, Jian L, Bing H, Xie G. Oxidation kinetics and phase evolution of a $\mathrm{Fe}-16 \mathrm{Cr}$ alloy in simulated SOFC cathode atmosphere. Journal of Power Sources. 2006;158:354-60.

[33]Sang S, Li W, Pu J, Jian L. Novel Al2O3-based compressive seals for IT-SOFC applications. Journal of Power Sources. 2008;177:77-82. 
[34]Hua B, Kong Y, Zhang W, Pu J, Chi B, Jian L. The effect of Mn on the oxidation behavior and electrical conductivity of $\mathrm{Fe}-17 \mathrm{Cr}$ alloys in solid oxide fuel cell cathode atmosphere. Journal of Power Sources. 2011;196:7627-38.

[35] The Oxide Handbook, ed. G. V. Samsonov. 1973, New York: Plenum Data Corporation. 524.

[36]A.V. Virkar, D.M. England. US 6,054,231, Solid oxide fuel cell interconnector. April 25, 2000. 
Appendix

SOFC solid oxide fuel cell

OCV open circuit voltage

ASR area specific resistance

DR degradation rate

SLM standard liter per minute

CTE coefficient of thermal expansion

$\mathrm{E}_{\mathrm{N}} \quad$ Nernst potential

$\mathbf{R}_{i} \quad$ total resistance of all cell components

$\eta_{L} \quad$ voltage loss caused by leakage

$\eta_{\text {aa }} \quad$ activation over potentials of anode

$\eta_{\text {ac }}$ activation over potentials of cathode

$\eta_{\text {ca }}$ concentration over potentials of anode

$\eta_{c c} \quad$ concentration over potentials of cathode

$i_{s} \quad$ constant operating system current density

$t_{0} \quad$ initial starting time

$\rho \quad$ electrical resistivity

t thickness of oxidation scale 


\section{Figure Captions:}

Fig. 1 - Schematic view (a) and assembled stack view (b) of the external-manifold stack with cross-flow configuration.

Fig. 2 - Mass flow rate distribution in the manifold: (a) the schematic view of the manifold; (b) the gas flows without resistance; (c) the gas flows with resistance of 600 $\mathrm{Pa}$; (d) the gas flows with resistance of $1200 \mathrm{~Pa}$

Fig. 3 - Cell voltage and power density as a function of current density for 10-cell stack $\left(9 \times 9 \mathrm{~cm}^{2}\right.$ active area per cell $)$ at $750^{\circ} \mathrm{C}$

Fig. 4 - Degradation of 10-cell stack under the current density of $370 \mathrm{~mA} / \mathrm{cm}^{2}$ at $750^{\circ} \mathrm{C}$.

Fig. 5 - Calculated ASR(t) per cell and average degradation rate of 10-cell stack under $370 \mathrm{~mA} / \mathrm{cm}^{2}$ constant load at $750^{\circ} \mathrm{C}$.

Fig. 6 - SEM micrograph of the cross section of single cell used in 10-cell stack, (a) the thickness of electrolyte is about $10 \mu \mathrm{m}$ and cathode is about $5 \mu \mathrm{m}$, (b) shows the microstructure details of the porous anode supporter, sintered particles have an average diameters of about $1 \mu \mathrm{m}$.

Fig. 7 - X-ray diffraction patterns of $\mathrm{NiO} / \mathrm{YSZ}$ anode layer before and after reduction.

Fig. 8 - X-ray diffraction patterns of LCN before and after test.

Fig. 9 - SEM morphologies and particle sizes before (a) and after (b) test of LCN powder.

Fig. 10 - ASR analysis of LCN contact material employing four-electrode method.

Fig. 11 - Photograph of cathode side of cell (a) and X-ray diffraction patterns of $\operatorname{LCN}(b)$.

Fig. 12 - Photograph of anode side with cell and interconnect.

Fig. 13 - Cross-sectional SEM morphologies with the EDS compositional analysis of anode $(a, c)$ side of interconnect and cathode $(b, d)$ side of corrugation.

Fig. 14 - The estimation of degradation composition. 

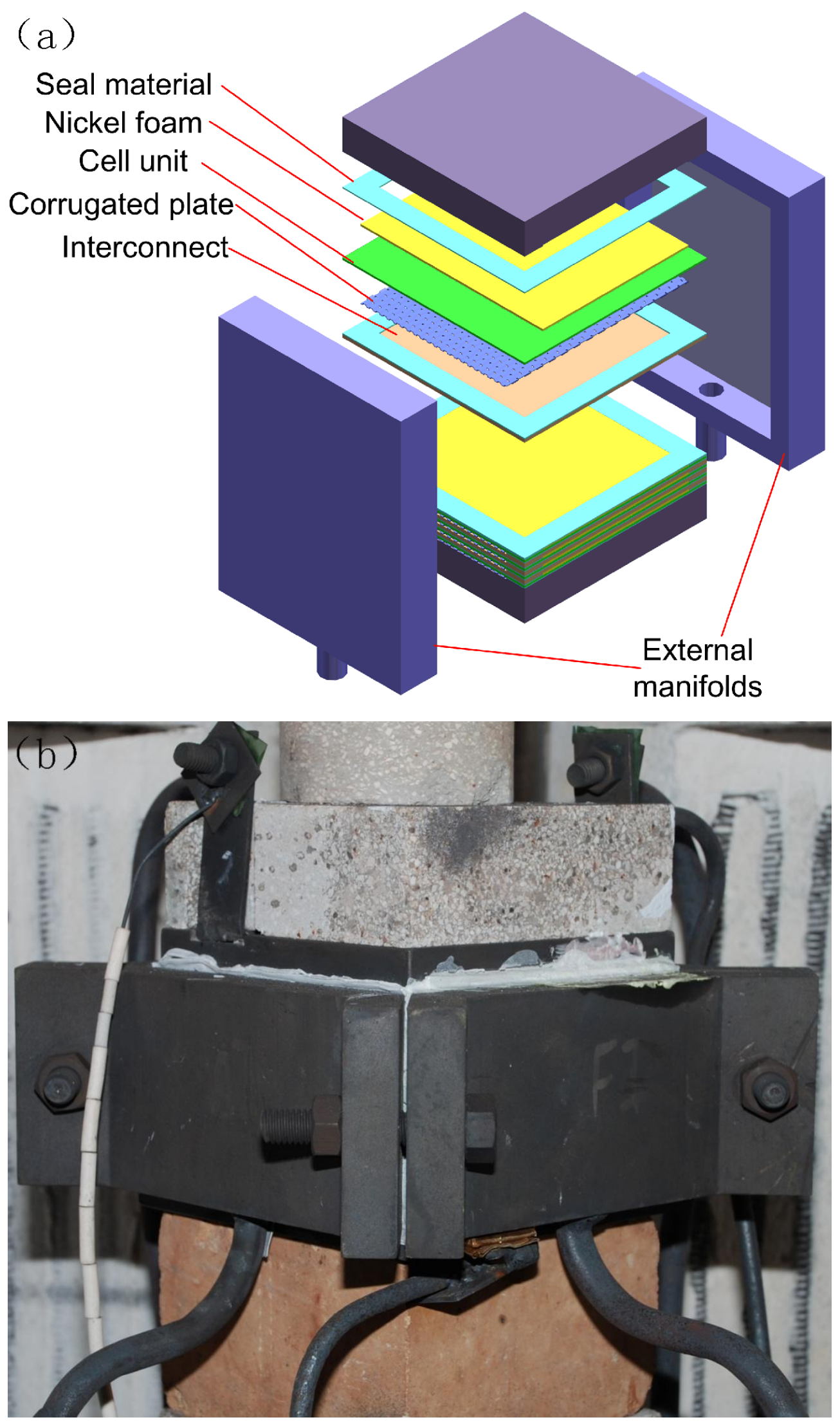

Fig. 1 - Schematic view (a) and assembled stack view (b) of the external-manifold stack with cross-flow configuration. 

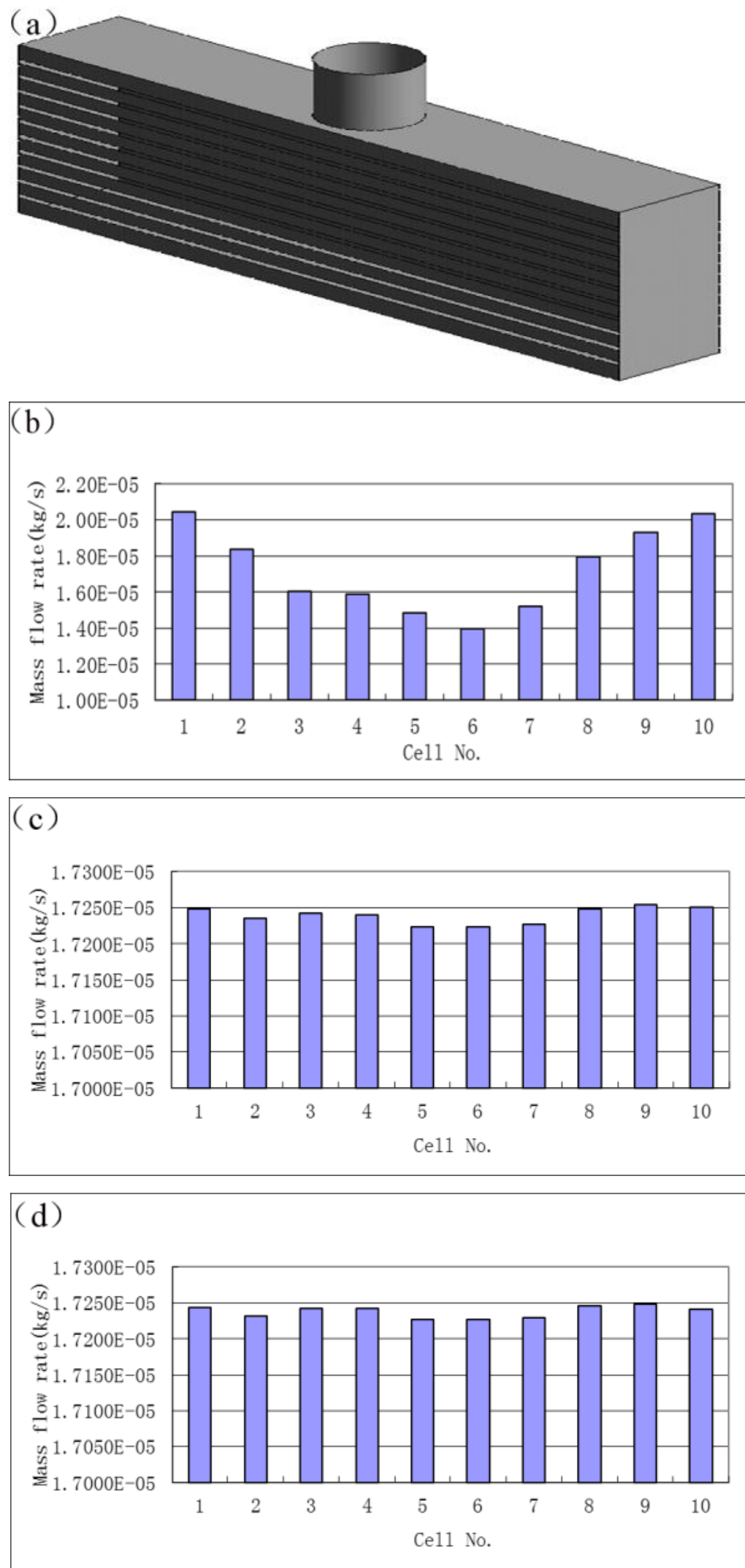

Fig. 2 - Mass flow rate distribution in the manifold: (a) the schematic view of the manifold; (b) the gas flows without resistance; (c) the gas flows with resistance of $600 \mathrm{~Pa}$; (d) the gas flows with resistance of $1200 \mathrm{~Pa}$ 


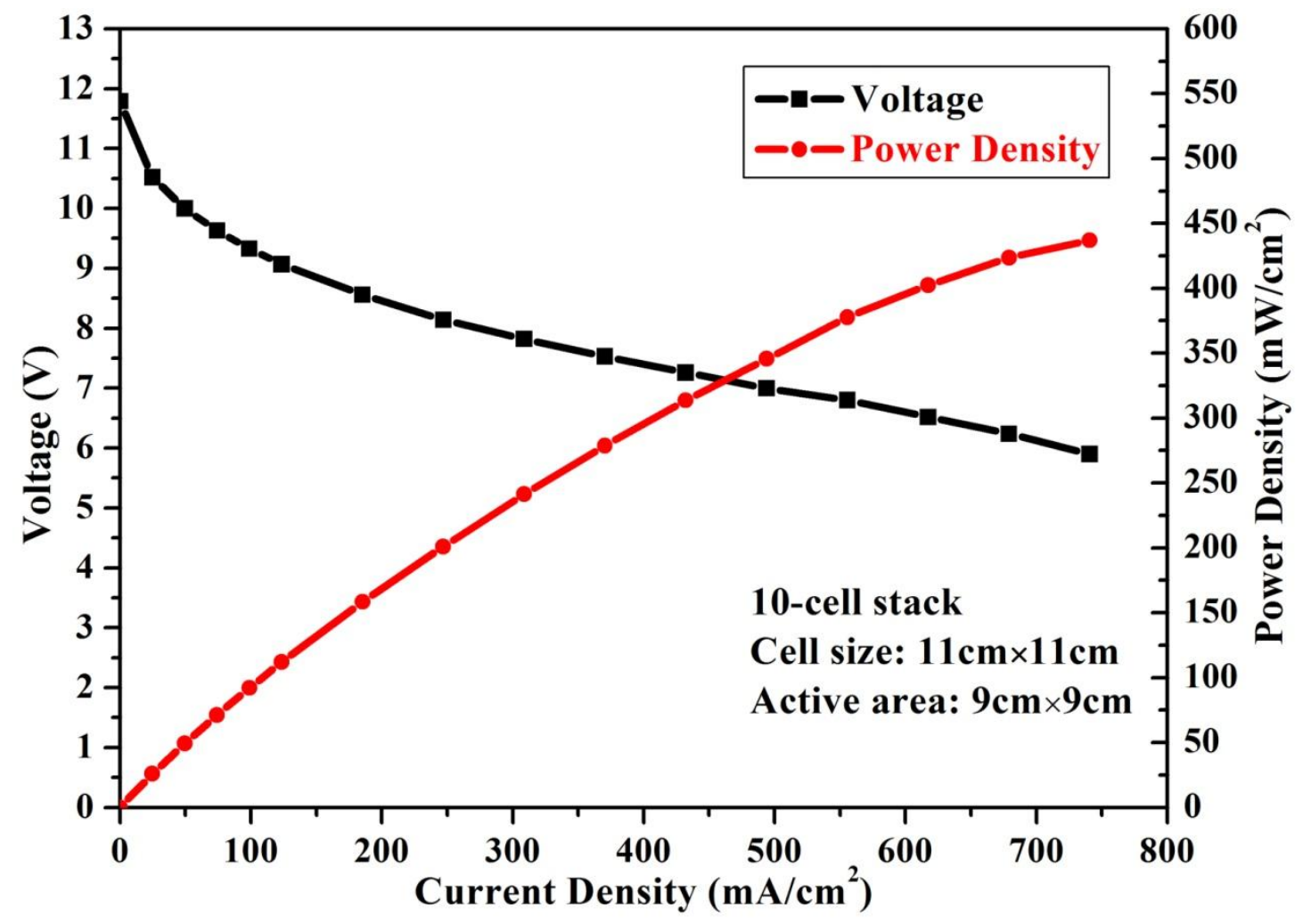

Fig. 3 - Cell voltage and power density as a function of current density for 10 -cell stack $\left(9 \times 9 \mathrm{~cm}^{2}\right.$ active area per cell $)$ at $750^{\circ} \mathrm{C}$ 


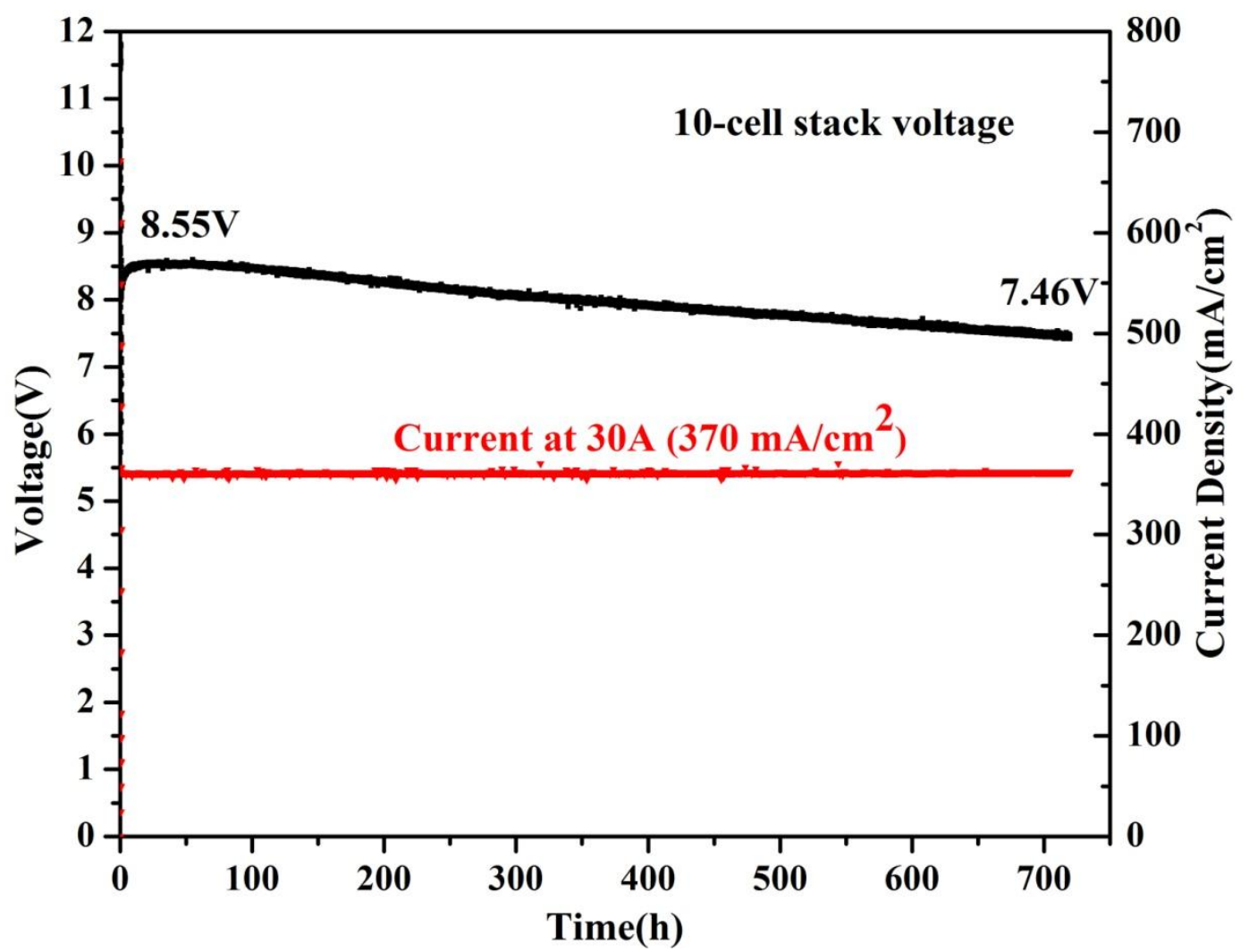

Fig. 4 - Degradation of 10-cell stack under the current density of $370 \mathrm{~mA} / \mathrm{cm}^{2}$ at $7^{750}{ }^{\circ}$. 


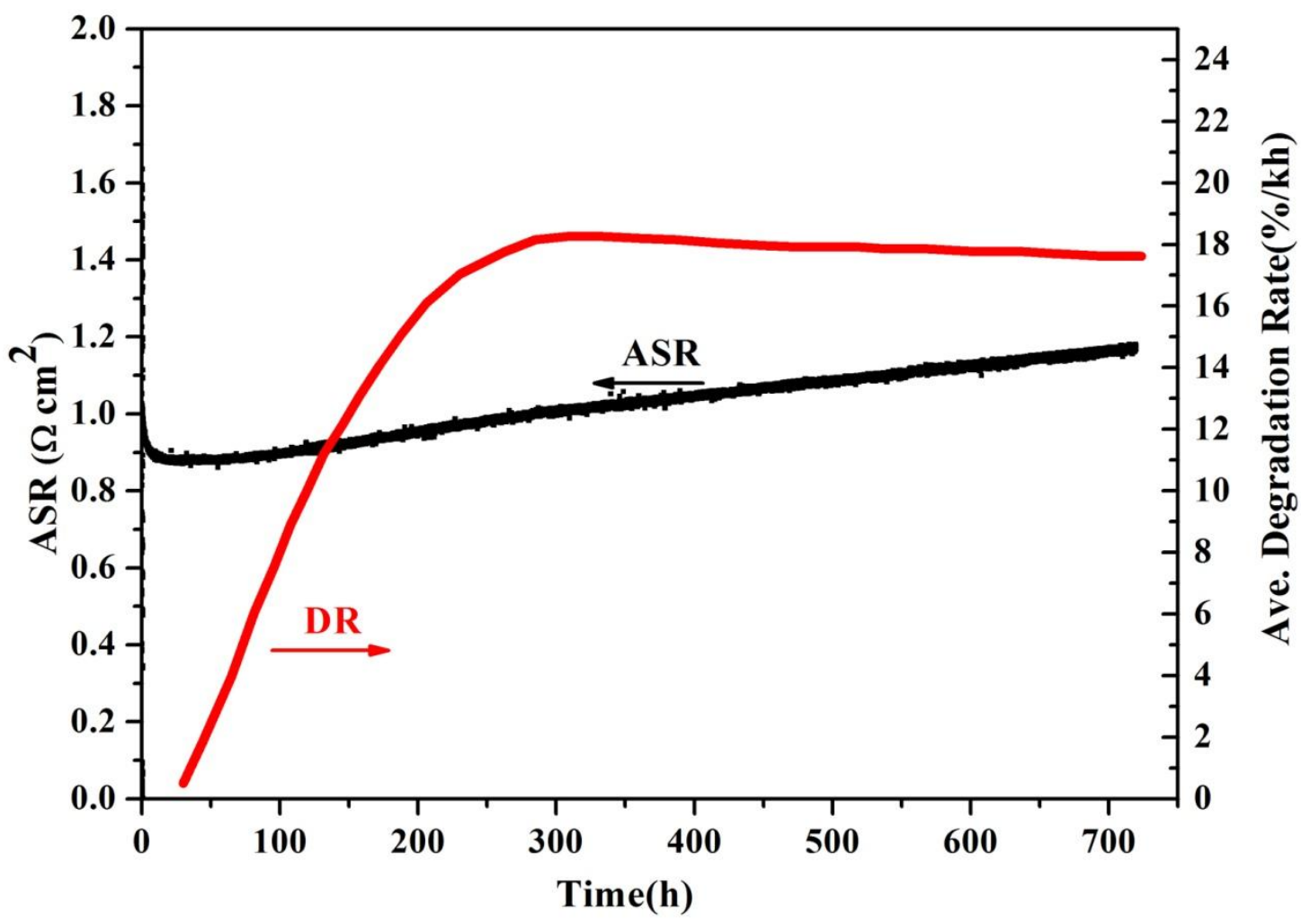

Fig. 5 - Calculated ASR(t) per cell and average degradation rate of 10-cell stack under $370 \mathrm{~mA} / \mathrm{cm}^{2}$ constant load at $750^{\circ} \mathrm{C}$. 

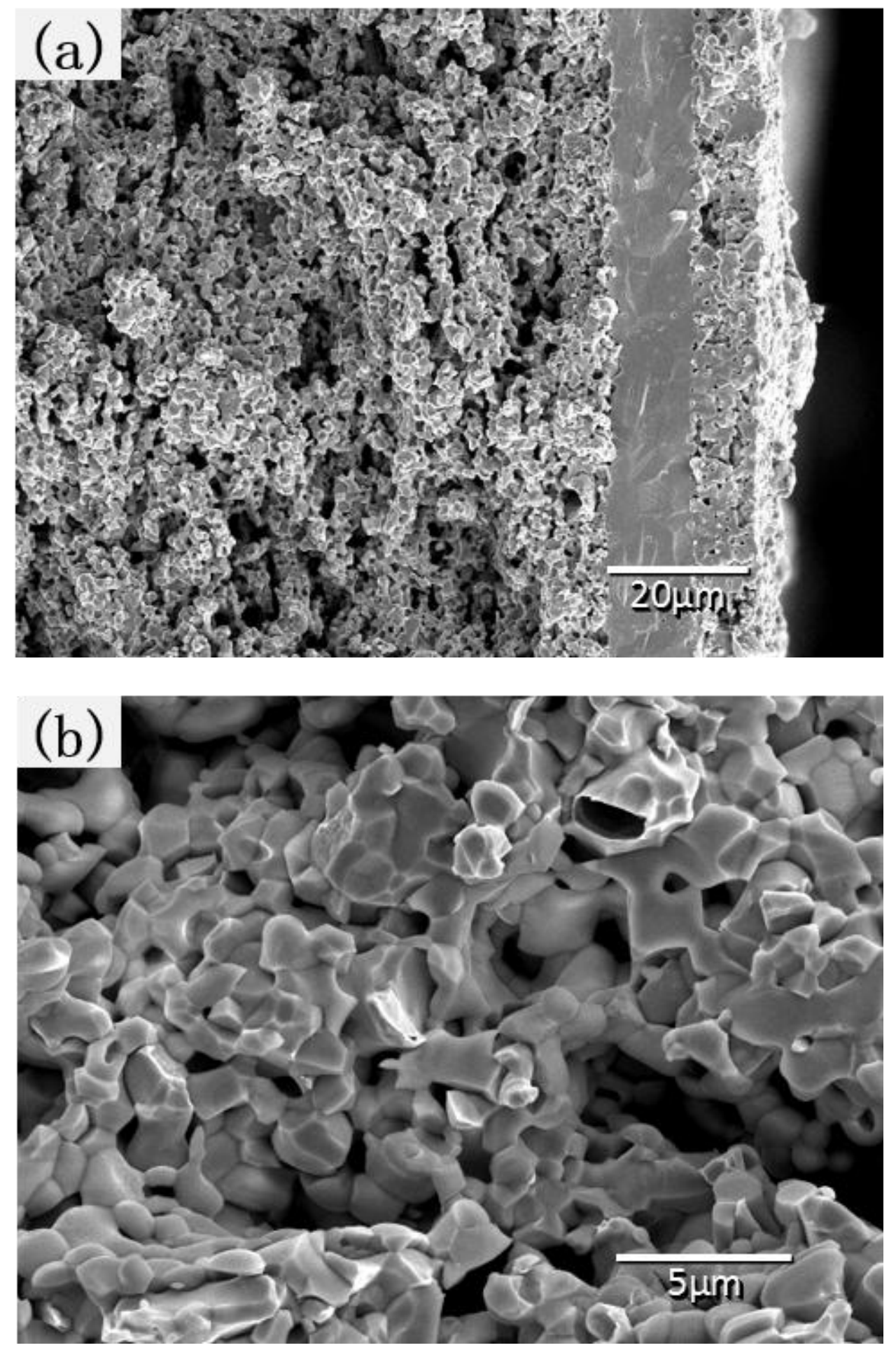

Fig. 6 - SEM micrograph of the cross section of single cell used in 10-cell stack, (a) the thickness of electrolyte is about $10 \mu \mathrm{m}$ and cathode is about $5 \mu \mathrm{m}$, (b) shows the microstructure details of the porous anode supporter, sintered particles have an average diameters of about $1 \mu \mathrm{m}$. 


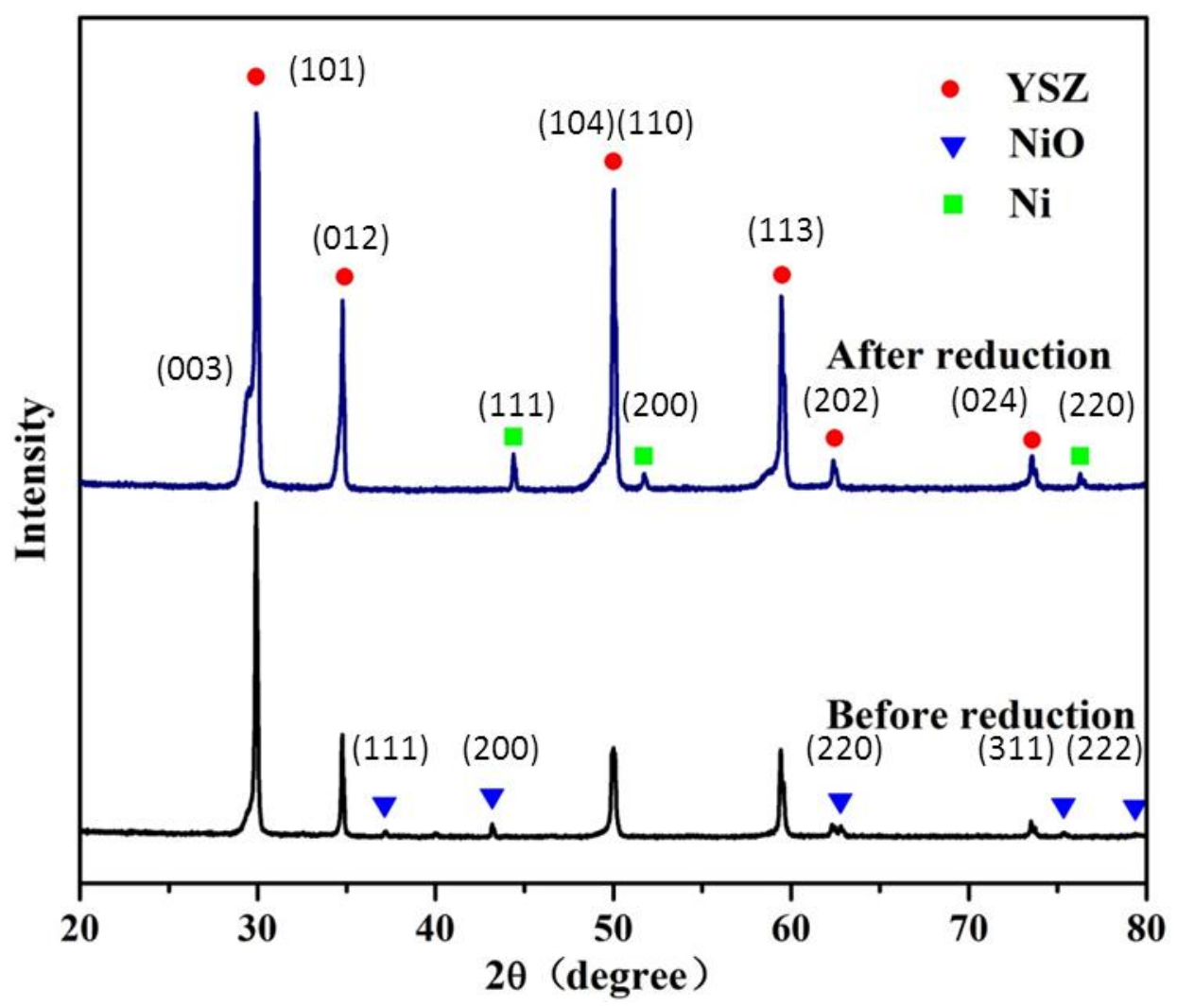

Fig. 7 - X-ray diffraction patterns of NiO/YSZ anode layer before and after reduction. 


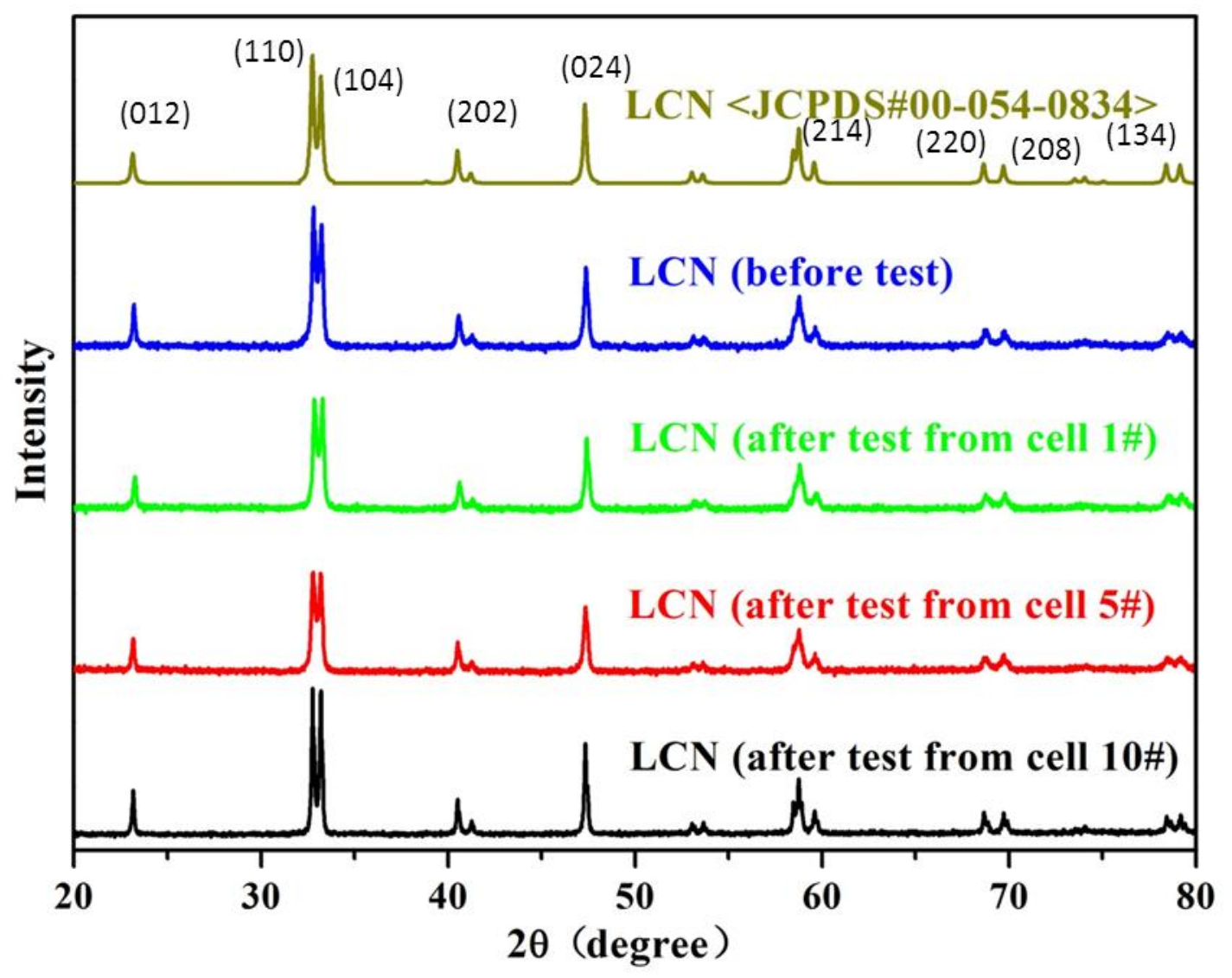

Fig. 8 - X-ray diffraction patterns of LCN before and after test. 

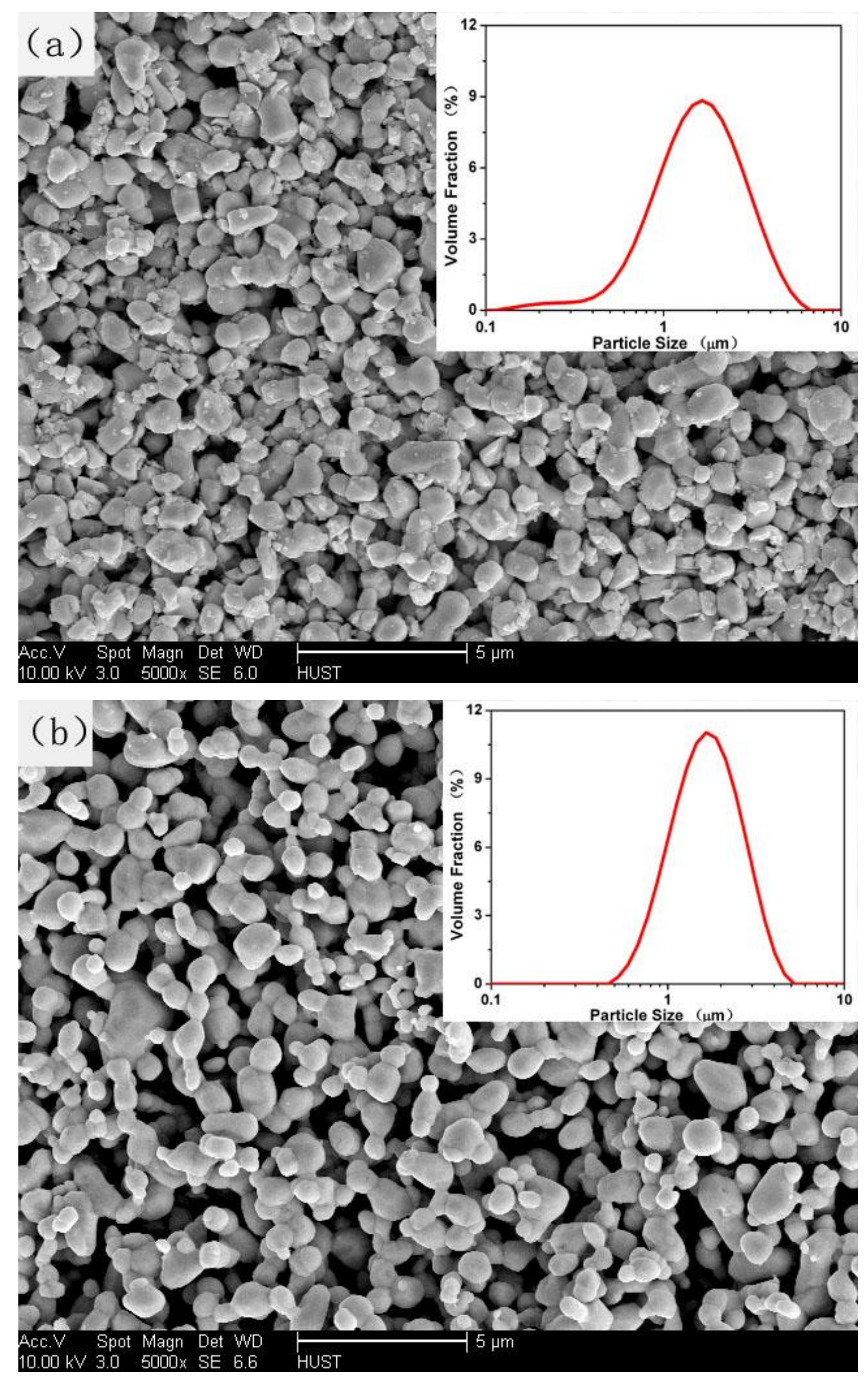

Fig. 9 - SEM morphologies and particle sizes before (a) and after (b) test of LCN powder. 


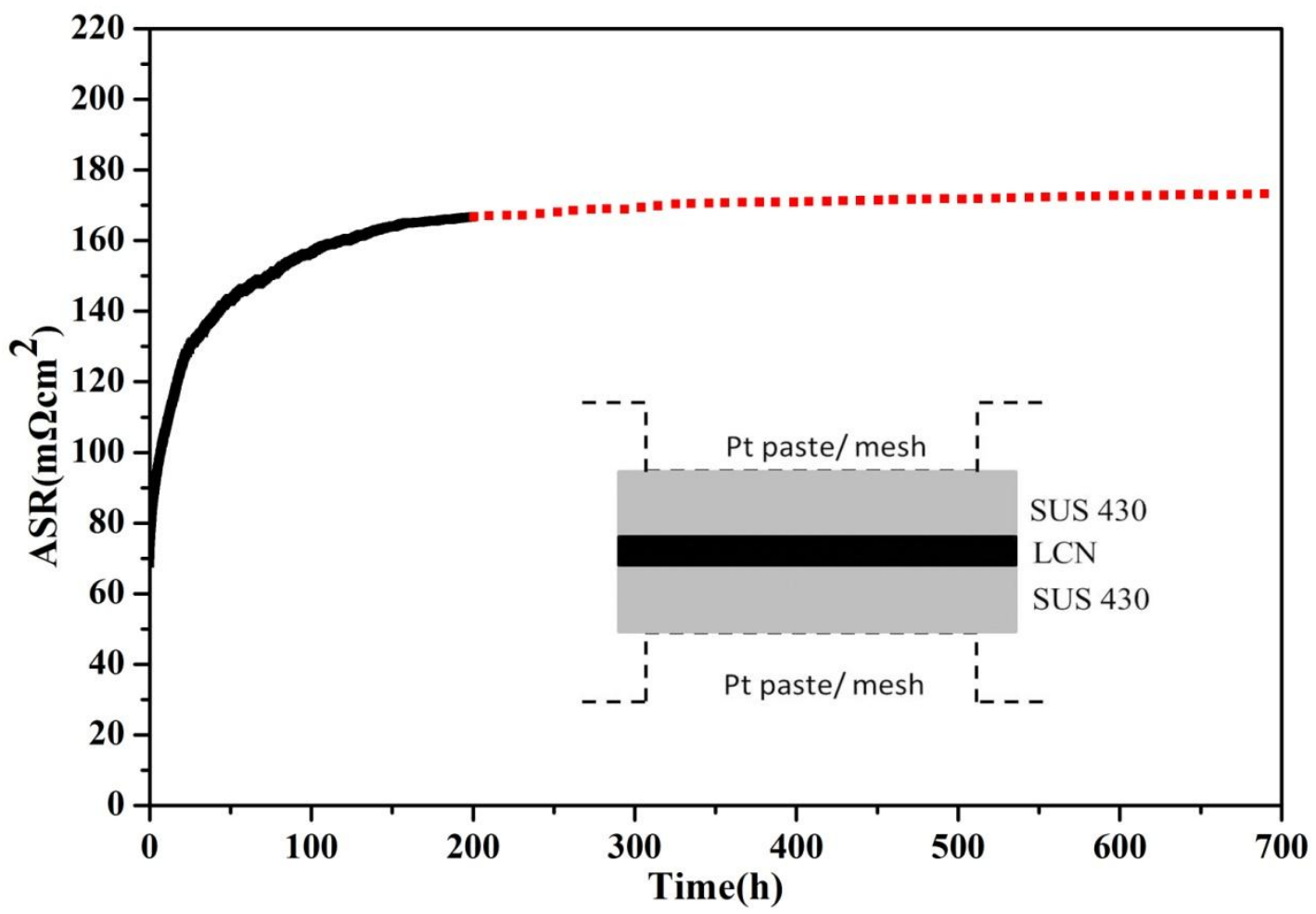

Fig. 10 - ASR analysis of LCN contact material employing four-electrode method. 

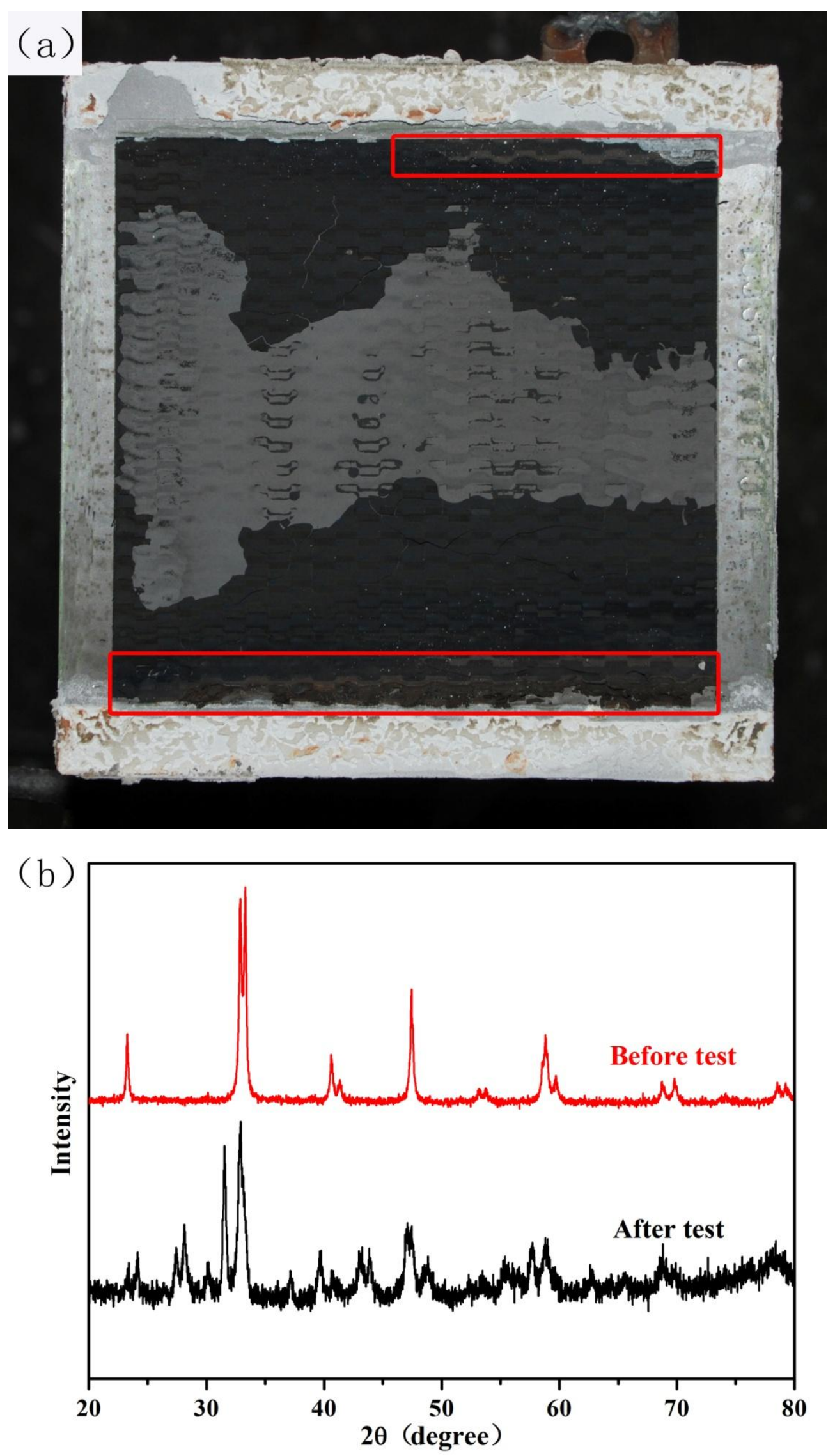

Fig. 11 - Photograph of cathode side of cell (a) and X-ray diffraction patterns of LCN (b). 


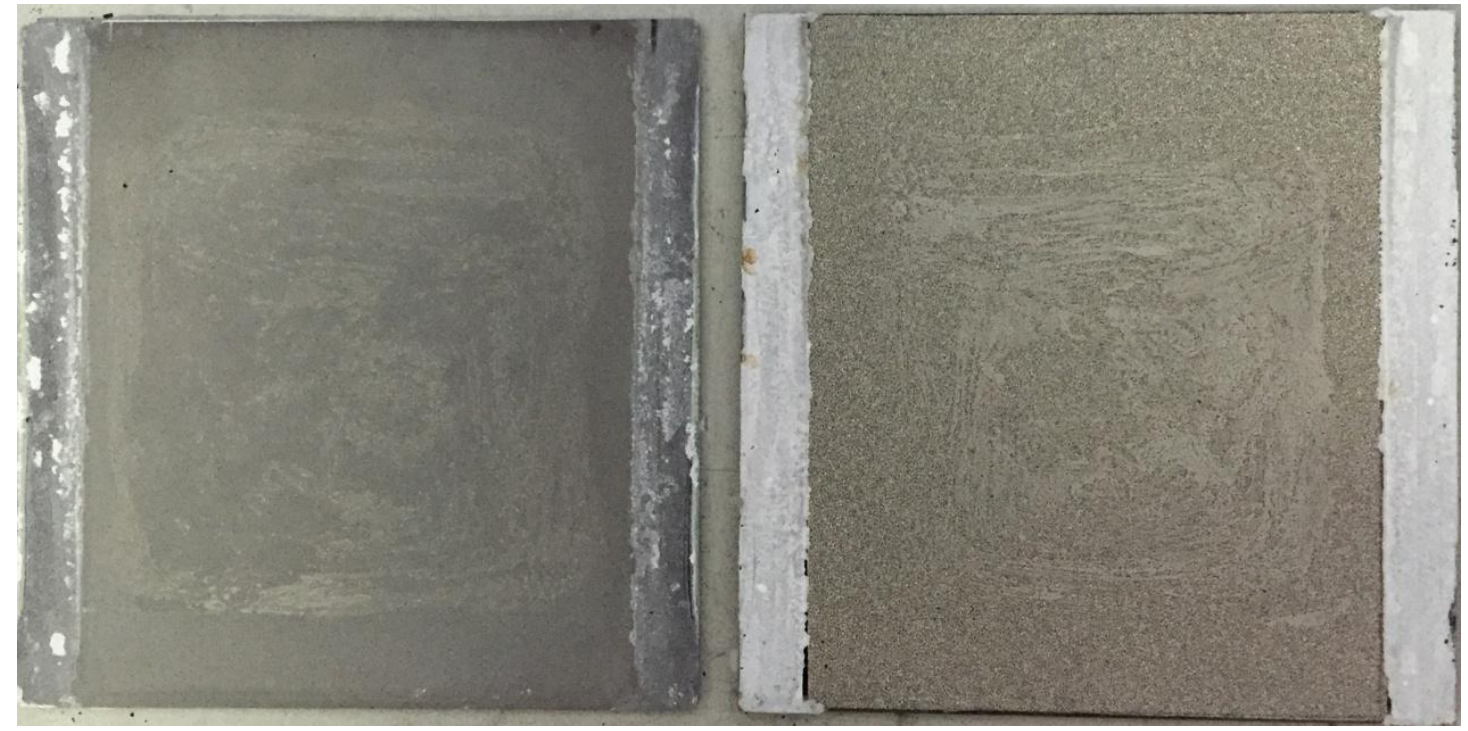

Fig. 12 - Photograph of anode side with cell and interconnect. 


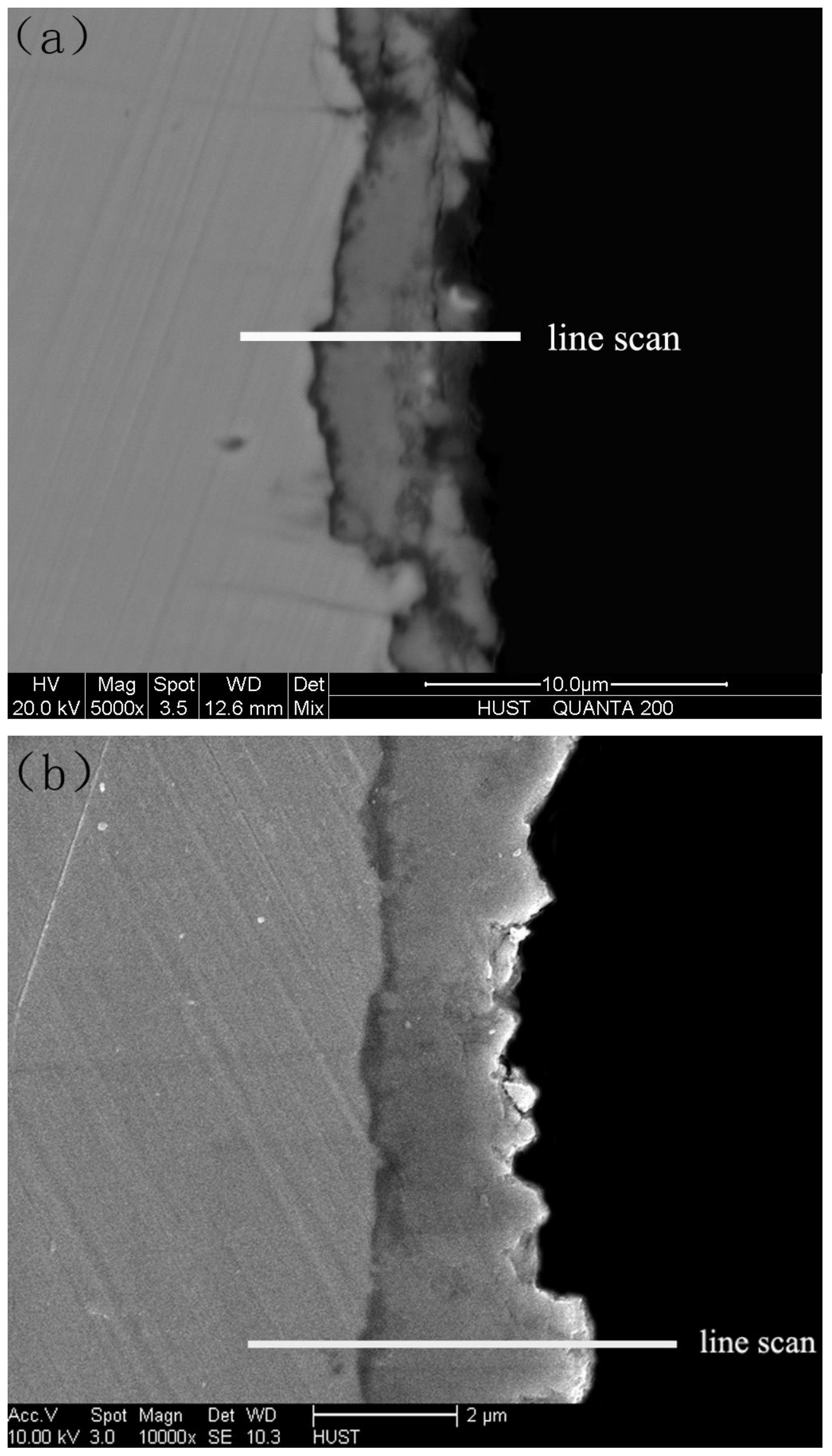



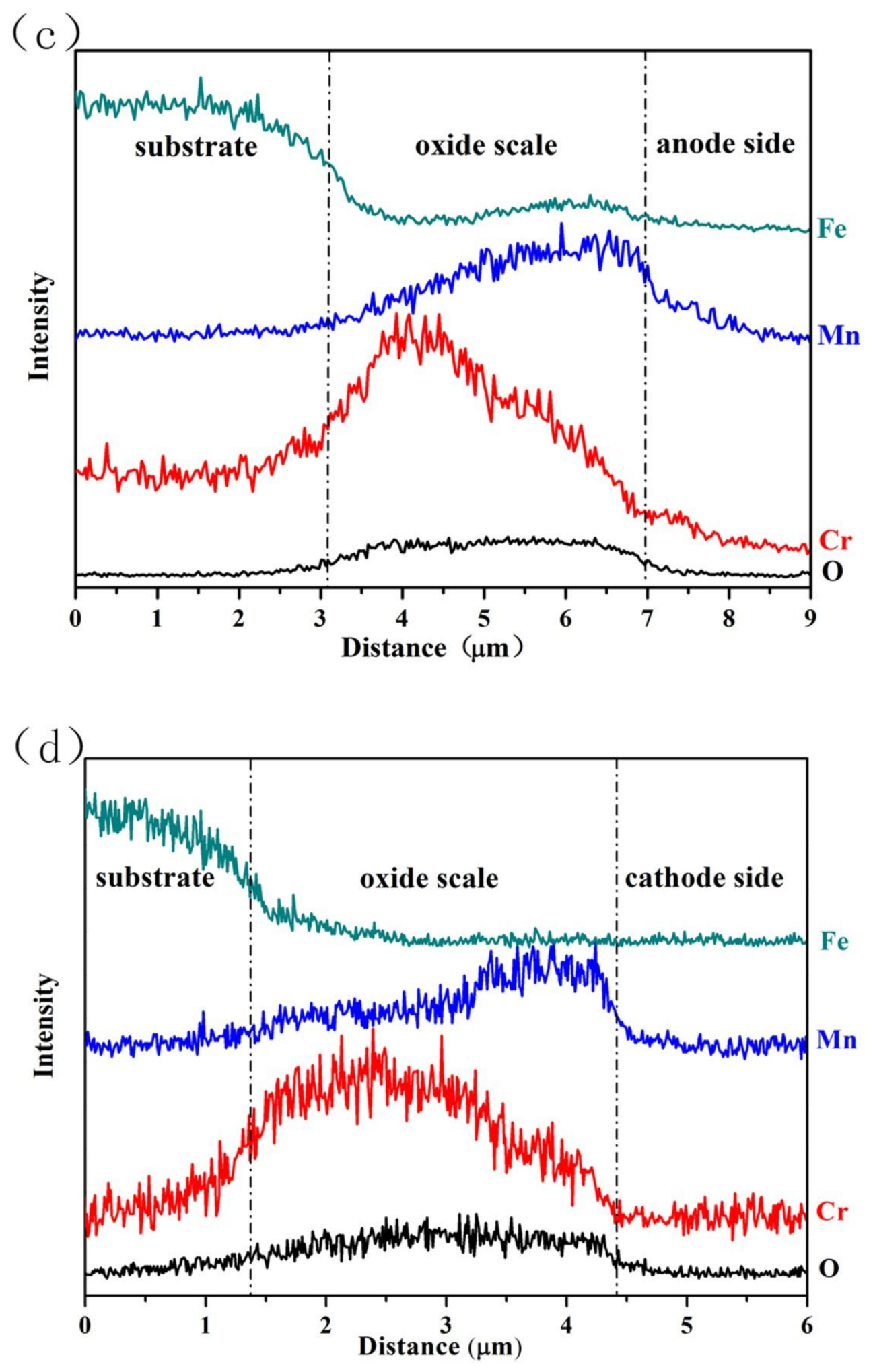

Fig. 13 - Cross-sectional SEM morphologies with the EDS compositional analysis of anode (a, c) side of interconnect and cathode (b, d) side of corrugation. 


\section{Performance Degradation analysis}

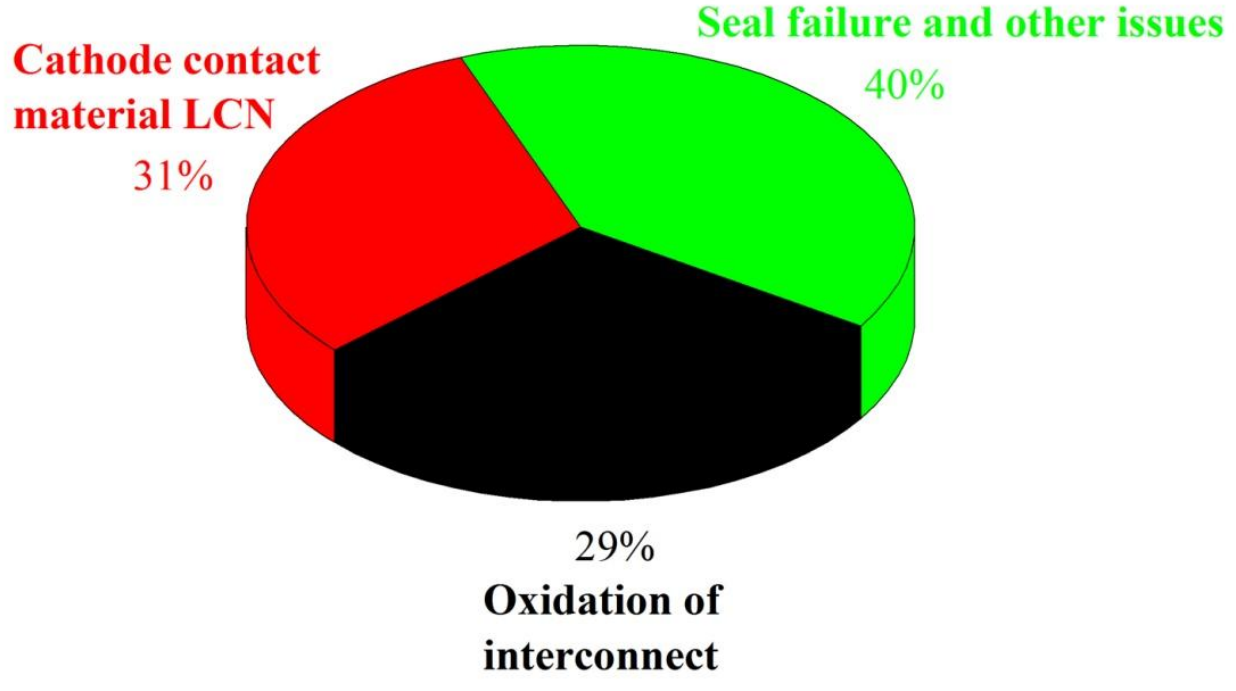

Fig. 14 - The estimation of degradation composition. 